\title{
DIGITAL PROMOTION OF LOCAL TOURIST DESTINATIONS IN THE NEW NORMAL ERA AND ITS EFFECT ON THE ECONOMY IN INDONESIA
}

\author{
Melly Maulin Purwaningwulan \\ Department of Communication Science, Universitas Komputer Indonesia, Bandung, Indonesia \\ Tias Dwi Ramdan \\ Department of Communication Science, Universitas Komputer Indonesia, Bandung, Indonesia
}

\begin{abstract}
This study aims to analyze the Digital Promotion of Local Tourist Destinations in the New Normal Era and Its Effect on the Economy in Indonesia. The research uses a case study method and data collection through in-depth interviews and online observations. Informants were determined by purposive sampling technique consisting of the government, the community, and tourism communication experts. The results show that the promotion objective is to maximize tourism potential and economic recovery through the tourism sector. Marketing targets include mapping four perspectives. Design messages and media containing travel invitations using health protocols (maintaining distance, wearing masks, washing hands, limiting interactions, staying away from crowds) and messages with CHSE standards (Cleanliness, Health, Safety and Environment Sustainability). Promotional mix carried out by advertising and Public Relations. The evaluation includes the evaluation of health protocols through focus group discussions. In conclusion, the digital promotion of local tourist destinations has been maximal but flexible by looking at every development of the pandemic condition-the impact of this research for policy considerations to revive the tourism industry and the economy.
\end{abstract}

Keywords: Digital Promotion, Local Tourist Destinations, New Normal Era

DOI: http://dx.doi.org/10.15549/jeecar.v9i1.873

\section{INTRODUCTION}

Digital promotion is a broad term that refers to various promotional techniques used to reach customers using digital technology. It includes a broad selection of services, product tactics, and brand marketing, which primarily uses the internet as a core promotional medium, alongside traditional $\mathrm{TV}$ and radio. Digital marketing includes assembling internet marketing techniques, such as Search Engine
Optimization (SEO), Search Engine Marketing (SEM), and link building (Uraltas, 2014). Marketing requires a strategy to market products to consumers. In competition, companies must be able to offer greater value and customer satisfaction than their competitors. Marketing is a social process by which individuals and groups obtain what they need and want through creating and exchanging products and value with others (Kotler, 2009). Promotion is carried out 
following the objectives applied. Promotion is a communication activity either directly or indirectly from individuals, groups, or organizations that facilitate the exchange of information to persuade one or several people or the general public to accept the products produced by a person, organization, or company (Liliweri, 2011).

Amid enormous expectations in the tourism sector, COVID-19 surfaced in Wuhan, China. This virus was detected at the end of 2019. Within three months, this virus transformed into a pandemic that hugely impacted various sectors, not only in their home country but throughout the world. Indonesia is one of the victims. When COVID-19 arrived in the country in March 2020, the government took immediate action.

Furthermore, social distancing must be applied. The Health Protocol Movement (Wearing Masks, Washing Hands, and Keeping Distance) was socialized, followed by Large-Scale Social Restrictions (PSBB) in various regions. Health comes first, and travel outside the home is restricted. This step is not much different from the steps taken in other countries. (Minister of Tourism, 2021).

Since Covid-19, research on Covid-19 has sprung up. Previous research has only been around the impact of Covid-19 on the tourism industry. As researched by Anele, Tourism plays a significant role in the economic development of Indonesia, which is now threatened by the pandemic. Based on the existing research, it has shown that the spread of Covid-19 resulted in travel suspension, partial economic lockdown, and restriction of movement, which adversely affected the tourism sector in Indonesia (Anele, 2021).

There are a couple of research on the development of interest in traveling in the new normal era. Ramayani, Yusuf \& Veranita analyzed that the millennial group has a high interest in continuing to travel and is the right target for disseminating tourism information. These millennials are a group that is reliable enough to enliven the world of traveling, tourist visits, and supporting the development of tourism in Indonesia. Their closeness to the world with the development of digital technology, online business, and social media is beneficial in disseminating information about tourism, national tourism, and internationally (Yusuf \& Veranita, 2021).
Furthermore, research on tourist behavior developed in the pandemic era. The behavior change was conveyed in Suprihatin research by analyzing tourist consumer behavior in the Covid-19 pandemic. It was found that having a good understanding and sensitivity to the motivation of tourist consumers will make it easier for producers to identify tourist needs as indicated by purchasing decisions as a reflection of consumer behavior (Suprihatin, 2020).

Another research concerns the effectiveness of technology as a tourism destination marketing tool. According to Chucu, technology was visibly effective in keeping destinations relevant and competitive, primarily through social media, as physical tourist activities were limited due to the pandemic. The technology assessment revealed that E-tourism played a key role in filling the gap left by destination closures and restrictions to travel, which motivated the increased use of virtual museums (Chucu, 2021).

The results of research from Wang \& Xiang explain that collaboration with tourism organizations is needed to advance the tourism industry, which will advance the country's economy. This research develops an integrative theoretical framework to explore the nature and dynamism of collaborative marketing efforts at the destination level (Wang \& Xiang, 2007).

However, there are still many elements of tourism marketing that have not been researched. The results of previous studies can be used as a basis for this research, which comprehensively examines digital promotion and its impact on the economy.

Therefore, the purpose of this research is to analyze the Digital Promotion of Local Tourist Destinations in the New Normal Era and Its Effect on the Economy in Indonesia, especially how Bogor Regency Government's Digital Marketing Communication Strategy Through Instagram Social Media Accounts @ bogor SportAndTourism in Promoting Tourist Attractions in Bogor Regency. Bogor Regency has many tourist destinations, especially in the natural tourism charm sector, so Bogor Regency is referred to as the "city of a thousand waterfalls". In addition, Bogor Regency also has a variety of tourist charms in the artificial tourism sector, including the Jungleland recreation park, The Jungle water park, and the Indonesian Safari Park Zoo. As for the choice of cultural tourism charms such as Cinangneng Cultural Village, 
Malasari Cultural Village, and many more. (https://bogorkab.go.id/category/potensi).

This study intends to analyze how the implementation of digital promotions by local governments in Indonesia promotes their local tourist destinations; how they synergize with programs that have been planned and implemented by the central government to revive Indonesian tourism. The novelties of this research are to analyze in detail the process of planning messages and digital promotional media, various examples of promotional mix programs adapted to pandemic conditions and evaluation processes that can be used as examples for other countries in promoting their tourism destinations. Research like this is still rarely carried out in Indonesia because the tourism industry is still trying to rise and return to glory with new habits. From the explanation above, the following problems are formulated:

1. How to Determine Digital Promotion Goals in Promoting Indonesian Local Tourist Destinations in the New Normal Era?

2. How is Digital Promotion Targeting to Promote Indonesian Local Tourism Destinations in the New Normal Era?

3. How to Design Digital Promotional Messages and Media in Promoting Indonesian Local Tourist Destinations in the New Normal Era?

4. How is the Development of Digital Promotion Promotional Mix in Promoting Indonesian Local Tourist Destinations in the New Normal Era?

5. How is Digital Promotion Evaluated in Promoting Indonesian Local Tourist Destinations in the New Normal Era?

\section{METHOD}

There must be a plan and design to make the research run well in conducting research.
According to Sarwonno, the notion of research methods is similar to a road map to determine the direction of study following the researcher's objectives (Sarwonno, 2006). Researchers use qualitative methods such as interviews, observations, and use of documents. According to Lincoln and Guba stated in Lexi J. Moleong, the uniqueness of qualitative research methods is that humans are considered the main actors. Also, it uses natural settings, uses sources' views to collect data, describes data inductively, sequences theory from bottom to top (such as ground theory), and interprets data effectively (Moleong, 2021).

According to Creswell in the book Research Methodology for Quantitative and Qualitative Public Relations, Ardianto stated that the descriptive-qualitative method is a postpositivistic research view. The opinion of one who is an example of the core of postpositivism research which is a form of data, instructions, and logic. Researchers gather information through its application using in-depth field data collection techniques at the research site (Ardianto, 2011).

The subject of this research is Indonesia. The observations and interviews were conducted at different places and times. The interviews were conducted single day mutually agreed upon with the informant. Observations are carried out by evaluating and participating in tourism programs held and analyzing social media that promote tourist destinations. The technique of determining informants is to use purposive sampling, namely sampling of data sources with the consideration of taking people who are considered to know best about what we expect to make it easier for researchers to explore the object of research. Researchers determined two key informants and two supporting informants (See Table 1).

Table 1: Research informants

\begin{tabular}{|c|l|l|}
\hline No & \multicolumn{1}{|c|}{ Full Name } & \multicolumn{1}{c|}{ Information } \\
\hline 1 & Zaenal Syafruddin & Head of the Bogor Regency Tourism Regional Promotion Board \\
\hline 2 & Mey Cresentya Rahail & Bogor Branding Squad \\
\hline 3 & Bagum Farcianta & Bogor Regency Community \\
\hline 4 & Fikri Dwi Putra & Bogor Regency Community \\
\hline
\end{tabular}

Source: Author's work 
Data collection techniques used in this study was adjusted to the focus and objectives as follow:

\section{Literature Study}

Attempts to obtain information by reviewing the appropriate reference to the research include collecting and studying data derived from documents related to the object of this research. The authors collected data from various books and scientific works according to the subject of this research and evaluated the data obtained from the field.

\section{Field Study}

a. Interview

The interview was conducted directly (face-to-face interview) with stakeholders in the local tourism industry.

b. Observation

Observation is the process of observing and recording the symptoms of the research systematically.

c. Documentation

Data collection by taking data from records, documentation, administration following the research problem.

\section{d. Internet searching}

Data collection by equipping or searching the data needed through the internet.

Tests for the validity of the data include increasing persistence, discussing with colleagues, and member checking. Data analysis techniques include data collections, data reductions, presentations, and concluding.

\section{RESULTS AND DISCUSSION}

\section{Determine Digital Promotion Goals in Promoting Indonesian Local Tourist Destinations in the New Normal Era}

Determination of marketing objectives has an important input in the tourism promotion process in Bogor Regency. It is an effort by the Bogor Regency Government to strengthen tourism during this pandemic to build the proper positioning to win the competition. Of course, in setting this goal, they have an essential role in advancing Bogor Regency tourism, and programs from the government can run well. The researchers conducted interviews with both key informants and supporting informants to determine the Setting of Marketing Goals in the Marketing Communication Strategy in the Bogor Program Sports and Tourism.

Based on the results of interviews with informants, researchers obtained interview data related to the Determination of Marketing Objectives of the Bogor Regency Government through the Bogor Sport and Tourism Program in Promoting Bogor Regency Tourist Attractions.

\section{Maximizing the Tourism Potential of Bogor Regency}

The researcher interviewed a key informant, namely Mr. Zainal, the Chairman of the Bogor Regency Tourism Promotion Agency, and the informant answered:

"Hmm.... so this, the tourism potential destination of Bogor Regency has been proven to be able to have a positive impact with major changes in people's lives. Economically, tourism has an impact on expanding business and employment opportunities, increasing per capita income and increasing foreign exchange. In the field of social life, socio-cultural interactions occur between immigrants and local residents so that it can cause changes in the way of life of the community as well as social integration" (Zainal Syafruddin, interview, June 9, 2021).

\section{Economic Recovery Through the Tourism Sector}

Every program must have a goal so that the program's direction produces results. The following is the answer from the first key informant, Mr. Zainal Syafruddin with his answer:

"So, the Bogor Regency Government has established The City of Sport and Tourism as a work program for the Regent of Bogor, Ade Yasin and Deputy Regent of Bogor, Iwan Setiawan. During this pandemic, the sport and tourism program is here to help revive and restore the economy." (Zainal Syafruddin, interview, June 9, 2021).

From this statement, Mr. Zainal said that the Bogor Sport and Tourism program was one of the keys to economic recovery from regional potentials. The second key informant, Mrs. Mey Cresentya, said the same thing that the Bogor Sport and Tourism program had been studied, here are the answers: 
"Branding Sport and Tourism is not a random work program because it is the result of a study of the potential that exists in the Earth of Faithful Faith. This Sport and Tourism branding is based on our potential and achievements, such as 11 international golf courses, Pakansari Stadium with the 14th best architectural design in the world, Sentul Circuit, paragliding tours, Geopark Pongkor, etc" (Mey Cresentya, interview, June 9, 2021).

The Bogor district government's marketing objectives refer to the idea initiated by the Bogor Regent in activities through the Bogor Sport and Tourism program as tourism promotion. In the goals of the current Bogor Sport and Tourism program, it is the key to the economic revival of the Bogor Regency area. The program was carried out by the Bogor Regency Regional Promotion Agency, DISBUDPAR and the Bogor Branding Squad to make the program a success.

\section{Digital Promotion Targeting to Promote Indonesian Local Tourism Destinations in the New Normal Era}

Visits in for tours of course from various regions, which makes the interests of each region must be highlighted. This can attract tourists from various regions who will be curious to come for a vacation at tourist attractions. A beautiful place will definitely bring up new tourists who will visit. Bogor Regency has many beautiful places to visit. Various tourists are also attracted by the beauty of Bogor Regency. Not only the beauty that is offered, but from the infrastructure and facilities, and the communication process that occurs is good, and the service is also good.

\section{Mapping 4 (four) Perspectives}

"Speaking of strategic targets are mapped into 4 (four) perspectives. The first perspective is stakeholders, the second perspective is customer, the third perspective is an internal process, and the fourth perspective is learning \& growth" (Zainal Syafruddin, interview, June 12, 2021).

"The first perspective, namely stakeholders, is a perspective that symbolizes the outcome/impact that Bogor Regency wants to achieve. From the perspective of stakeholders, there are several strategic targets: "Increasing the contribution of tourism and the creative economy to economic resilience." The achievement of this strategic target is measured by 3 (three) strategic target performance indicators (IKSS).

The second perspective, namely the customer, is a perspective that describes the output of the Bogor Regency Government. With the resulting output, it is expected that the Bogor Regency Government's outcome can be realized via the Disbudpar Tourism Promotion Agency.

The third perspective, namely the internal process, is a perspective that describes the process carried out by the Disbubpar/promotional agency to produce output from the customer perspective. If the process has been carried out correctly, it is expected that the output from the customer's perspective can be realized. From this perspective, there are 3 (three) strategic targets, namely: "The implementation of study-based tourism and creative economy regulations," "Availability of data and information on the results of studies according to the needs of tourism and the creative economy", and "Increasing the quality and quantity of human resources for tourism and the creative economy".

The fourth perspective, namely learning and growth, is a perspective that describes the strategic plan of the Disbudpar or tourism promotion agency that is used to carry out the process from an internal process perspective" (Zainal Syafruddin, interview, June 12, 2021).

\section{Instagram Social Media Tracing Data}

The Instagram feature can be used as an option to determine targets. The workings of the feature are very simple, with a statement given by the second key informant, namely Mrs. Mey Cresentya, in classifying the tourist targets targeted by the Bogor Regency Government along with the answers:

"Hmmm, there are several categories regarding targeting, from Instagram it is very easy to know who the target is, it can be seen clearly in the Instagram features section, we can also see how old the tourist target is, male/female, can be classified clearly through new media this" (Mey Cresentya, interview, 12 June 2021).

The grouping process is also obvious following the results of researchers' observations in determining tourist targets from the Bogor sport and Tourism program to determine tourism targets (see Fig. 1-3). 


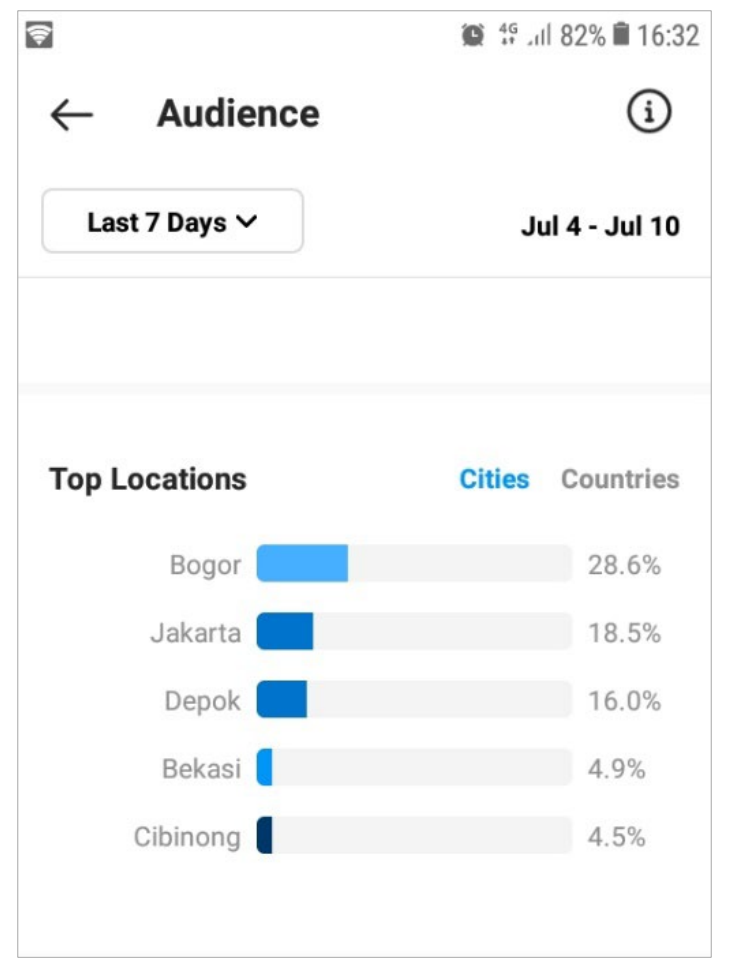

Figure 1: Target Tourists by Region

Source: Instagram Bogor_sportandtourism (2021)

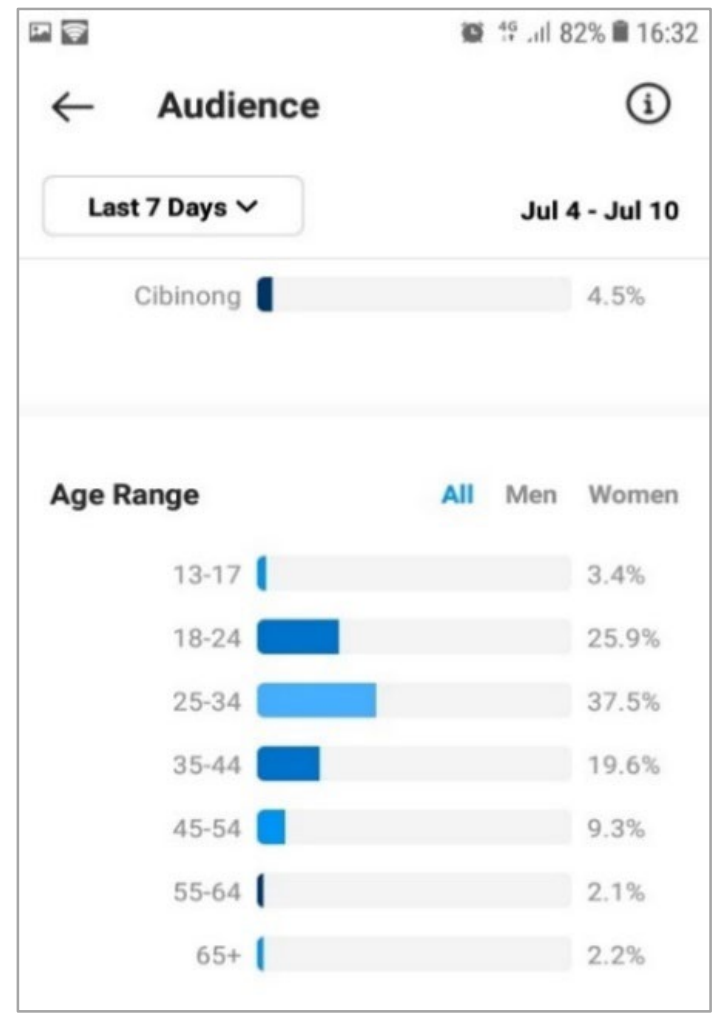

Figure 2: Target Tourists by Age

Source: Instagram Bogor_sportandtourism (2021)
These features are very fast in targeting because the government clearly knows the tourists visiting by region, date, day, and year. It adapts to the lifestyle of people who actively use social media, who desire to maximize new media in information dissemination activities related to promoting tourist attractions in Bogor Regency.

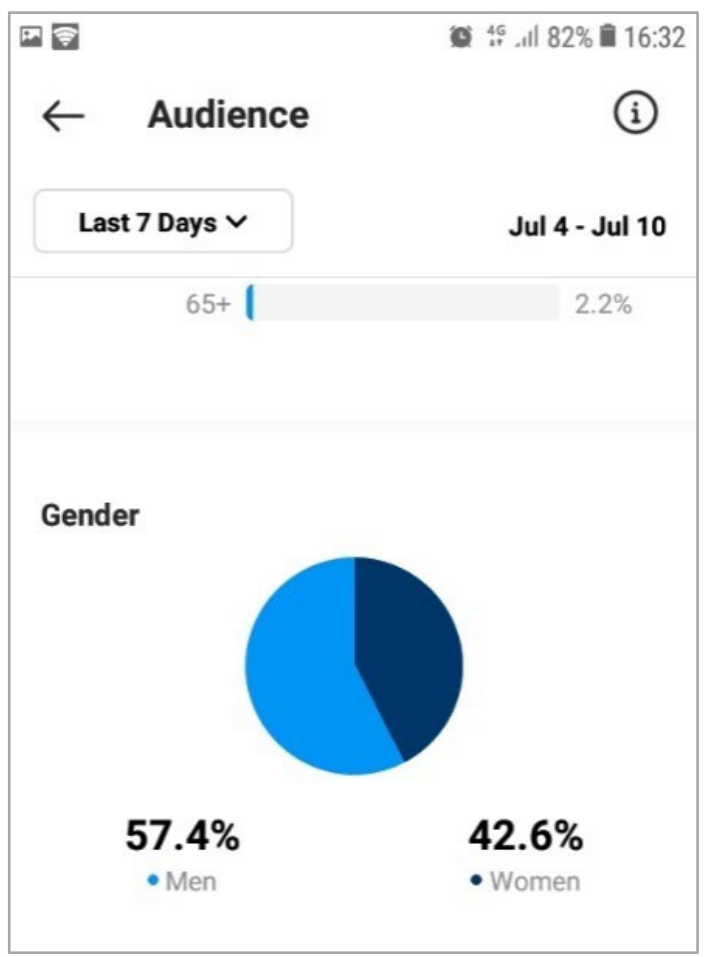

Figure 3: Target Tourists by Gender

Source: Instagram Bogor_sportandtourism (2021)

\section{Design Digital Promotional Messages and Media in Promoting Indonesian Local Tourist Destinations in the New Normal Era}

This pandemic has forced tourist attractions to adopt new habits to keep tourists safe, such as making handwashing stations everywhere and providing hand sanitizer. Message content and media play an important role for tourist attractions, to find out information through the media and what messages can be conveyed by tourist attractions.

\section{Order Follow Health Protocols When Traveling}

The researcher conducted interviews with the first key informant, namely Mr. Zainal Syafruddin as the chairman of the regional tourism 
promotion agency of Bogor Regency, who thought that:

"So people now like tourism places that have implemented the CHSE standard or Cleanliness, Health, Safety, and Environment Sustainability and this has also been implemented in Bogor district. By CHSE standards, at least people feel the place is clean. So there is a sense of comfort. Well, sustainable tourism is very popular. This means tourism in a more sustainable place. Back to nature. I am sure, everything is safe and has implemented the CHSE protocol, so let's go back to tourism in Bogor district as long as we always obey the protocol, everything will be safe" (Zainal Syafruddin, interview, June 12, 2021).
From this statement, there are several ways to make tourists awake and feel safe. The same thing was conveyed by a supporting informant, namely Bagum Farcianta, with the following answers:

"For now, health is the main priority, but Bogor Regency must continue to think about how health goes hand in hand with the economic movement of tourism by improving health protocols and in my opinion, antigen swab is not needed as long as it is in accordance with 5M" (Bagum Farcianta, interview, June 16, 2021). (See Fig. 4).

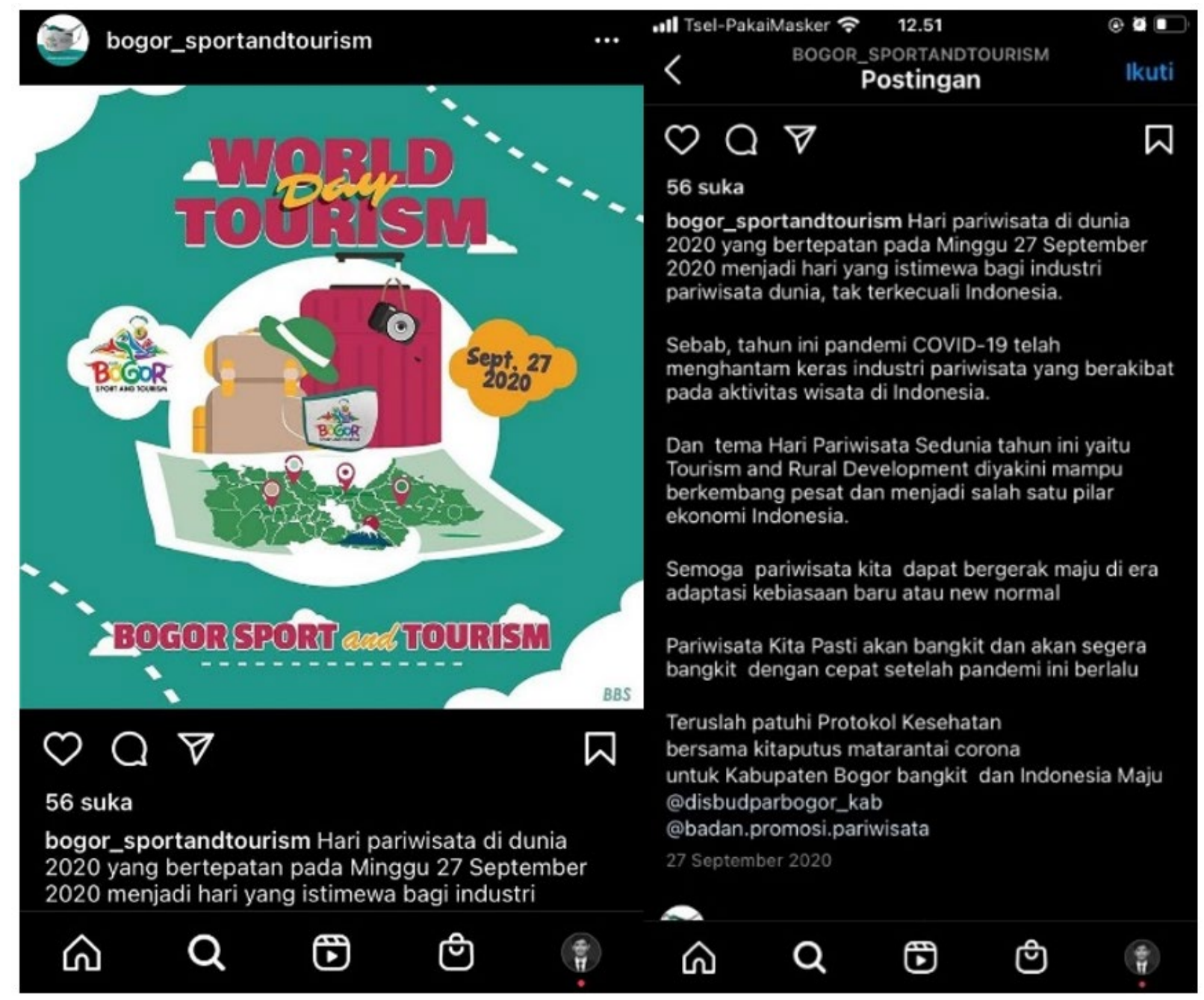

Figure 4: Order Follow Health Protocol

Source: Instagram Bogor_sportandtourism (2021) 
2. The Media Used by the Bogor Sport and Tourism Program to Promote Tourist Attractions

Various media in this day and age are easy to access by many people. Information can be obtained in various media. Of course, the role of the media is important in promoting tourism places. The researcher interviewed the first key informant, namely Mr. Zainal Syafruddin. Here is the answer:
"So the tourism industry, which is advancing rapidly, cannot be separated from the role of various media, including social digital media that promote it. One of them is the role of the media in informing tourism objects, to local tourists and foreign tourists. It is certainly very effective to be a reference for them in deciding their tourist destinations" (Zainal Syafruddin, interview, June 12, 2021). (See Fig. 5).

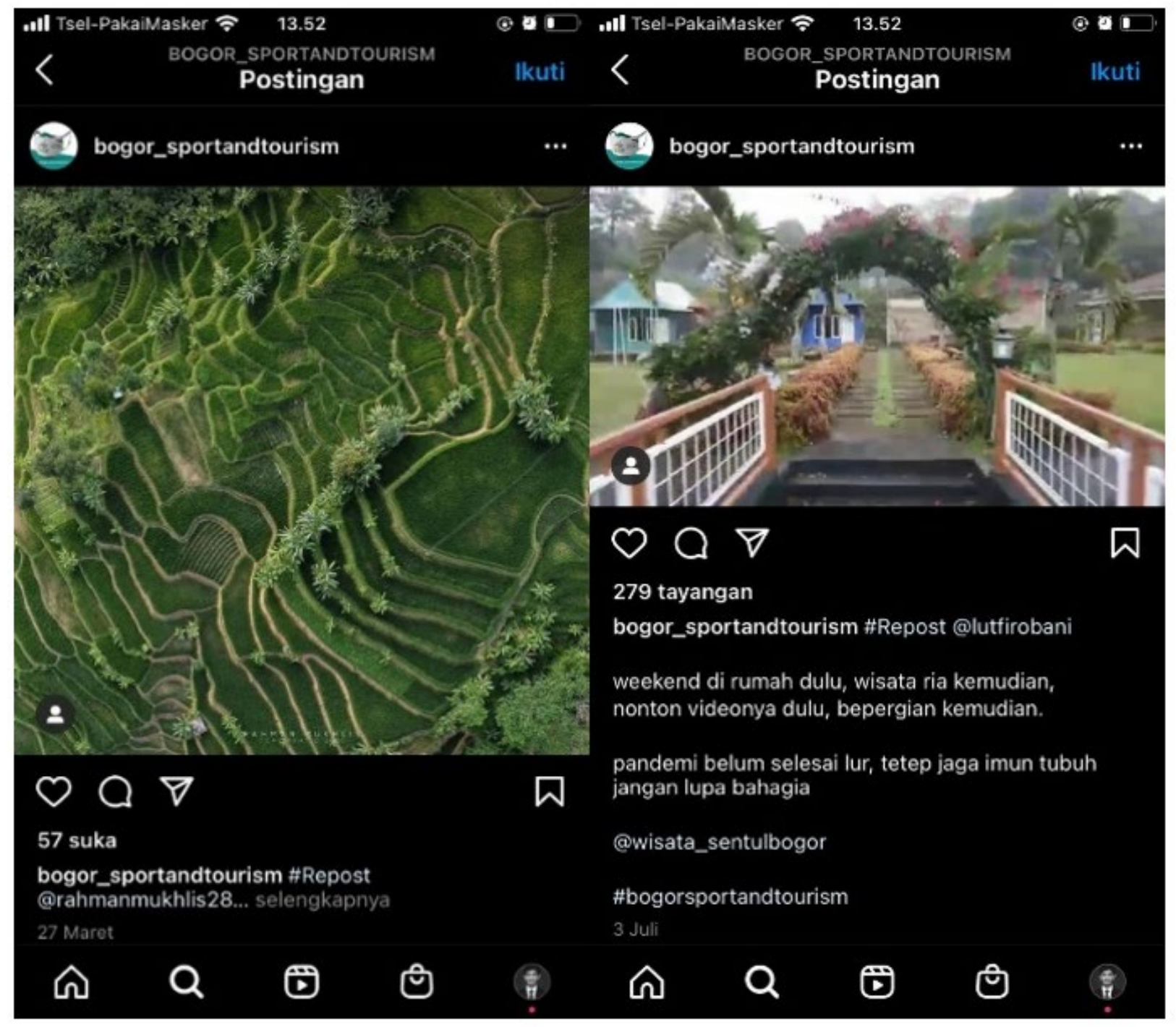

Figure 5: The Beauty of Bogor regency Tourism

Source: Instagram Bogor_sportandtourism (2021)

The Development of Digital Promotion

Promotional Mix in Promoting Indonesian Local Tourist Destinations in the New Normal Era
The Bogor Regency Government has developed several Promotional mixes to promote Bogor Regency tourism. Efforts are being made to promote tourism in order to 
revive the economy that is being affected by the pandemic.

\section{Advertising}

The role of advertising in the promotion process is important. If there is no advertisement, the audience will find it challenging to know the products/services offered. The following are the media used for advertisements carried out by the Bogor district government through the Bogor Sport and Tourism Program. The researcher interviewed with the first key informant, Mr. Zainal Syafruddin, with the following answers: "I think there are a lot of advertisements, hmm, what was that mix, so here's what we did there were a lot of advertisements in print media and then there were banners in the form of an invitation to travel, I think a lot of it was implemented in the form of this fish" (Zainal Syafruddin, interview, June 12, 2021).

From the statement above, advertisements in the form of banners containing invitations to travel are installed in various cities to create opportunities for various regions to be influenced to travel to Bogor Regency (See Fig. 6).

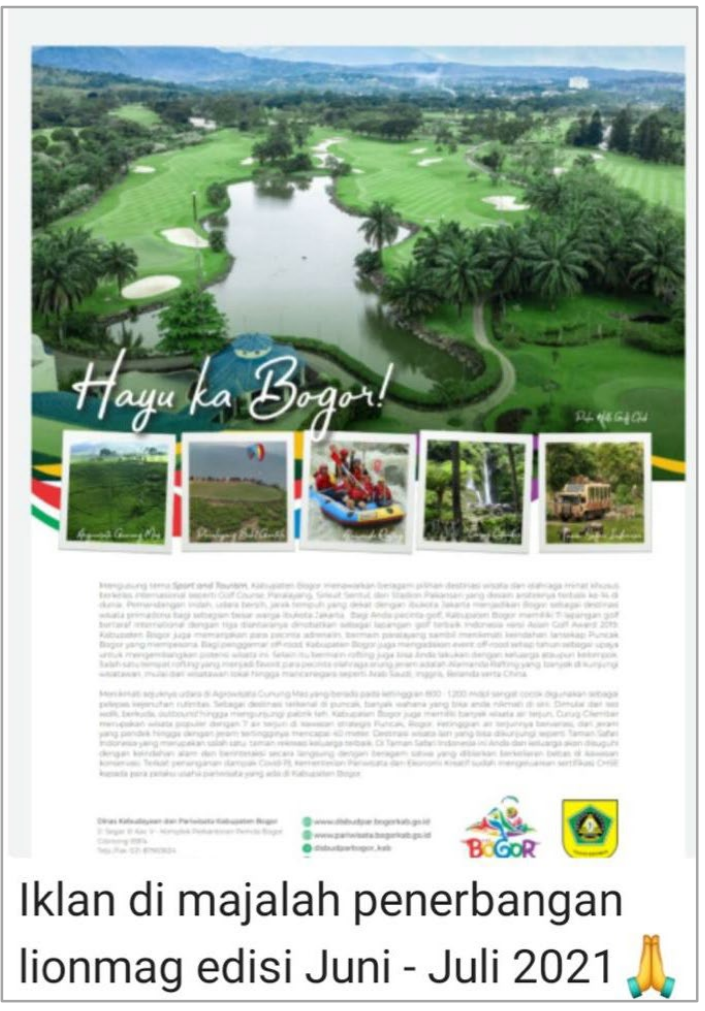

Figure 6: Articles in Lionmag Magazine Source: Bogor Branding Squad (2021)
Advertisements used to promote tourist attractions through Instagram are very cheap and effective because the content delivered is exciting. Simple strategies seem easy to reach tourists who want to know information through Bogor Sport and Tourism Instagram. Digital platforms are beginning to be used as primary channels for customer interaction and transactions, as well as a vehicle for creating innovative business models, including in the travel industry (Omarova, et al., 2021).

\section{Public Relations}

The role of public relations here is very important in promotion. Public relations can create events, collaborate with sponsors, and make the image of the Bogor Sport and tourism program seen as good for the community. Of course there are several things conveyed by key informants. the answer:

"A lot has been done in the context of economic recovery in the tourism sector, there is a tourism creative video competition event in 2020 where videos must promote the natural beauty of Bogor Regency for the nature category, promote artifacts or historical sites for the cultural heritage category, and promote hotels or culinary delights for the tourism sector. hotel restaurant category. Then display the health protocol" (Zainal Syafruddin, interview, June 12, 2021).

From the statement above, the competition aims to promote tourism villages from the Bogor district, and the participants are from the district community (See Fig. 7).

The news will add to the positive image that the Bogor district government can obtain in its efforts to restore the economy from the tourism sector. In addition to helping the community in their work through video competitions, the Bogor Regency government in the Bogor Sport and Tourism program received a positive response. Of course, behind all that, there is a public relations role that always tries to build a good image in the community and promote tourist attractions in Bogor Regency. 


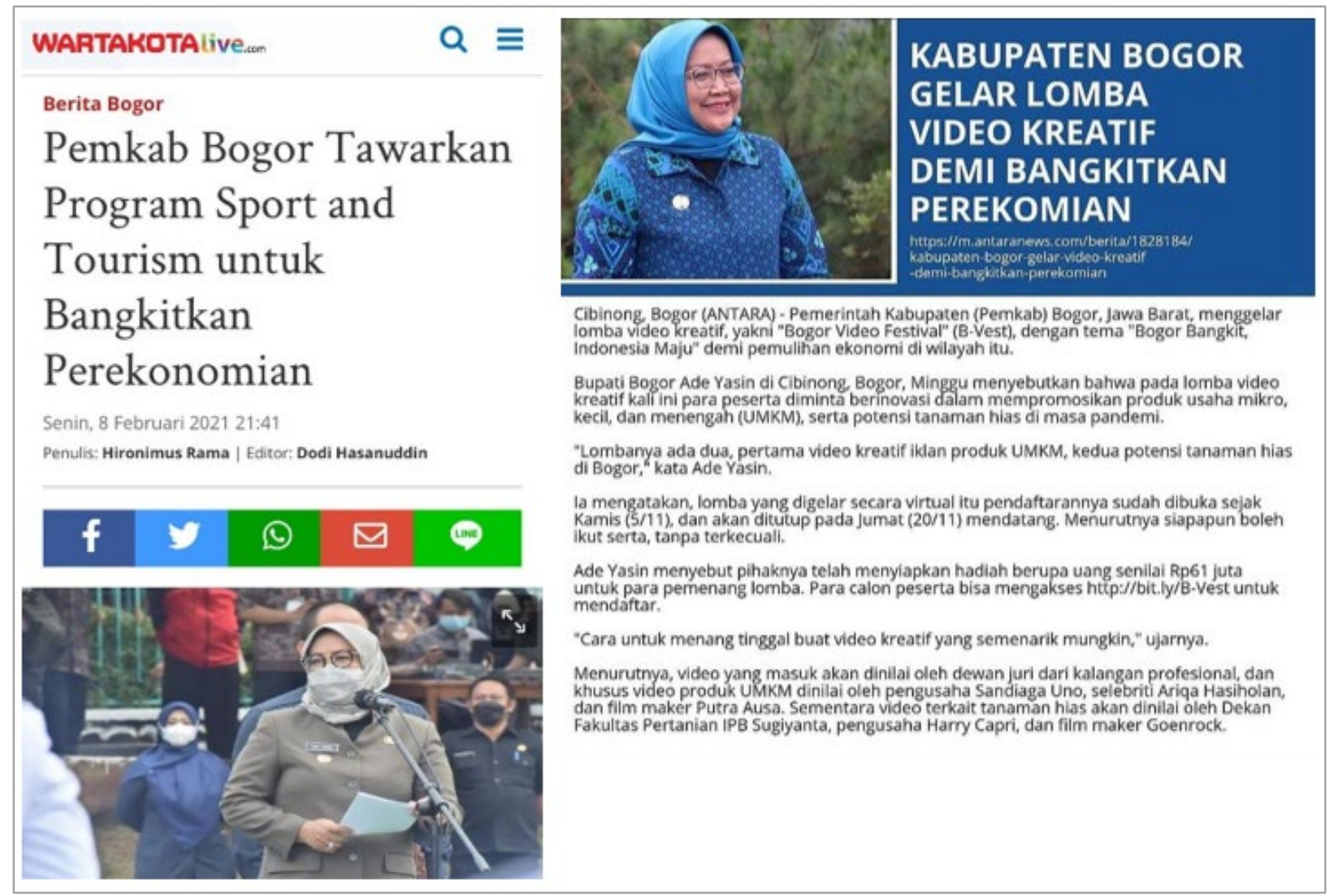

Figure 7: Online News

Source: Author's Work (2021)

\section{Digital Promotion Evaluated in Promoting Indonesian Local Tourist Destinations in the New Normal Era}

The evaluation is the last stage in the marketing strategy. After setting goals, designing messages and media and promotional mix, the next step is to evaluate the tourism marketing strategy carried out by the Bogor Regency government in the Bogor Sport and Tourism program. The COVID-19 pandemic has deepened social and economic inequalities and increased discrimination in hospitality and tourism services (Liu, et al., 2021).

\section{Evaluation of Health Protocol}

The evaluation of the Bogor Regency Government needs to be carried out because to improve the performance of the Bogor Sport and Tourism program. The researcher conducted interviews with the first key informant, namely Mr. Zainal Syafrudiin, by saying:

"Bogor Regent Ade Yasin has also on various occasions asked all relevant agencies to help increase the confidence of tourists to start traveling with health protocols. Therefore, we need several pillars that help increase a sense of security and comfort for tourists and all tourism actors, and the creative economy. Such as the $5 M$ health protocols (wearing masks, washing hands, maintaining distance, reducing mobility) and 3T (Tracing, Testing, and Treatment) must be expanded and improved. The main thing is geber, hurry and gaspol for all of that" (Zainal Syafruddin, interview, June 12, 2021).

\section{Evaluation of the Bogor Sport and Tourism Program}

Evaluation of the marketing of the Bogor Sport and Tourism program needs to be done for the explanation explained by the second key informant, namely Mrs. Mey. In her interview, she answered:

"It must be admitted that there are still many shortcomings in the Bogor Sport and Tourism program, especially in the marketing section. We always carry out evaluations after activities or 
events, and usually we will evaluate daily, monthly, weekly, yearly, and usually we invite tourism actors from the Bogor Regency area to discuss. Various strategies have also been prepared and are expected to help accelerate the recovery of the tourism sector and the creative economy." (Mey Cresentya, interview, June 12, 2021).

This shift has unprecedentedly led to substantial requirements and needs of hygiene management, social-distancing, and contactless services. In this context, AI-based robots and pertinent unmanned services have been largely proposed and adopted in different tourism and hospitality sectors (Zhang, 2021).

The construction of the brand destination image consists of identifying the most relevant associations of the destination and strengthening emotional bonds with the brand. A conceptual model of destination branding, reflecting these ideas and advocating that destination image is composed of three elements: global image, destination brand, and brand personality derived from this last (Morand, et al., 2021).

\section{CONCLUSION}

Tourism sector actors do not necessarily give up during the Covid-19 pandemic. Lots of creative activities related to tourism were encountered during the pandemic. The central government has been very responsive to its policies and support for the tourism sector. Through CHSE Certification, which grants certificates to Tourism Businesses, Tourism Destinations, and other Tourism Products to provide guarantees to tourists for implementing Hygiene, Health, Safety, and Environmental Sustainability. 9,596 tourism businesses have been certified from 398 regencies/cities and 34 provinces. Promotion is chosen through digital channels as a means of creation and expression. The use of social media, especially Instagram, simultaneously in promoting local tourism provides good information to the public. One of the highlights is the emergence of virtual walks, where tourists are invited to travel to several locations only through their cellphones. More than 64 locations in Indonesia can be visited by virtual means through various applications available on Google Playstore and App Store. The local government also seized the opportunity to hold this virtual event. Several virtual tourism events are already running in 2020 and 2021.
Suggestions from the results of this research is a practical guide that continues to be developed for tourist attractions in preparing products and services that are clean, healthy, safe, and environmentally friendly. An important component that becomes the main factor for tourist visits, as the basis for promotional programs, is tourist attractions. It includes everything that has uniqueness, beauty, and value in the form of a diversity of natural wealth, culture, and manufactured products that are the target or destination of tourist visits.

\section{REFERENCES}

Anele, K. K. Assessing the impact of COVID-19 on the Indonesian tourism industry. Journal of Indonesian Tourism, Hospitality and Recreation, 4(2), 107-120. https://doi.org/10.17509/jithor.v4i2,\%200ct ober.34393

Ardianto, E. (2011). Metodologi penelitian untuk public relations kuantitatif dan kualitatif. Bandung: Simbiosa rekatama media.

Buku Outlook Pariwisata Dan Ekonomi Kreatif Indonesia 2021 Kementrian Pariwisata Dan Ekonomi Kreatif.

Chuchu, T. (2021). Assessing the Effectiveness of Technology in Destination Marketing during the COVID-19 Pandemic. DOI:https://doi.org/10.24922/eot.v8i2.7459 7 https://bogorkab.go.id/category/potensi

Kotler, Philip. 2009. Marketing Management. Jakarta: Erlangga

Liliweri, A. (2011). Komunikasi Mass; Serba Ada Serba Makna. Jakarta: Kencana Prenada Media Grup.

Liu, J., Long, A., Li, M., \& Bai, B. (2021). Cyberbystanders' reactions toward tourism companies' prejudice practice during the COVID-19 pandemic. Journal of Hospitality and Tourism Management, 49, 74-83.

Moleong, L. J. (2021). Metodologi penelitian kualitatif. PT Remaja Rosdakarya.

Morand, J. C., Cardoso, L., Pereira, A. M., AraújoVila, N., \& de Almeida, G. G. F. (2021). Tourism ambassadors as special destination image inducers. Enlightening Tourism. A Pathmaking Journal, 11(1), 194-230.

Omarova, A., Nurumov, A., Karipova, A., Kabdullina, G., Aimurzina, B., \& Kamenova, 
M. (2021). Analysis of the Development of Innovative Activities of the Tourism Industry in the Influence of Pandemic. Journal of Environmental Management \& Tourism, $12(6$ (54)), 14421453.

Sarwonno, Jonathan. 2006. Metode Penelitian Kuantitatif Dan Kualitatif. Bandung: Graha Ilmu.

Suprihatin, W. (2020). Analisis Perilaku Konsumen Wisatawan Era Pandemi Covid19 (Studi Kasus Pariwisata di Nusa Tenggara Barat). BESTARI, 1(1), 56-66.

Uraltaş, N. T. (2014). New digital marketing actors: Private shopping clubs and their advertising practices. Journal of Media Critiques, 1(Special), 13-26.

Wang, Y., \& Xiang, Z. (2007). Toward a theoretical framework of collaborative destination marketing. Journal of Travel Research, 46(1), 75-85.

Yusuf, R., \& Veranita, M. (2021). Minat Berwisata Kaum Milenial Di Era New Normal. Jurnal Kepariwisataan Indonesia: Jurnal Penelitian dan Pengembangan Kepariwisataan Indonesia, 15(2), 158-167.

ZHANG, Y. (2021). A big-data analysis of public perceptions of service robots amid COVID19. Advances in Hospitality and Tourism Research (AHTR), 9(1), 234-242.

\section{ABOUT THE AUTHORS}

Melly Maulin Purwaningwulan, email: melly.maulin@email.unikom.ac.id

Melly Maulin Purwaningwulan, Program Studi Ilmu Komunikasi, Fakultas Ilmu Sosial dan Ilmu Politik, Universitas Komputer Indonesia, Bandung, Indonesia.

Tias Dwi Ramdan, Program Studi Ilmu Komunikasi, Fakultas Ilmu Sosial dan Ilmu Politik, Universitas Komputer Indonesia, Bandung, Indonesia. 